\title{
Isotopic provenancing of the Salme ship burials in Pre-Viking Age Estonia
}

\author{
T. Douglas Price ${ }^{1}$, Jüri Peets ${ }^{2}$, Raili Allmäe ${ }^{2}$, Liina Maldre ${ }^{2}$ \\ $\&$ Ester Oras ${ }^{3}$
}

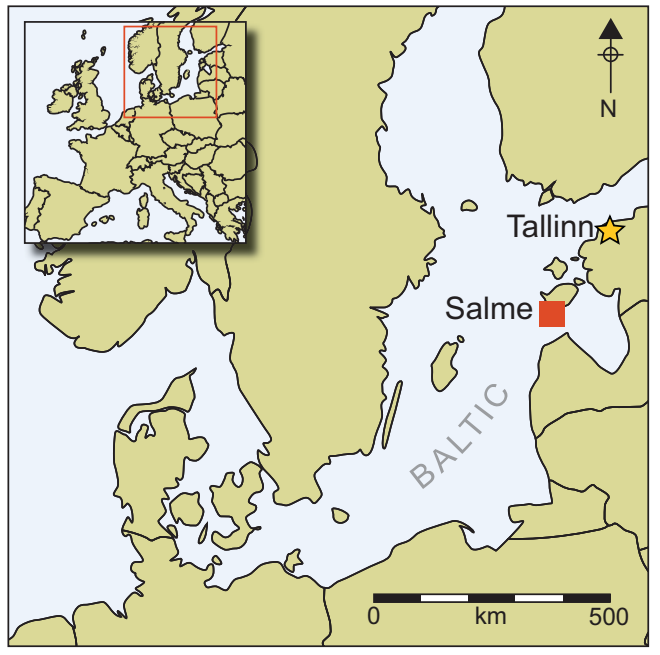

Ship burials are a well-known feature of Scandinavian Viking Age archaeology, but the discovery of 41 individuals buried in two ships in Estonia belongs to the Pre-Viking period and is the first of its kind in Europe. The two crews met a violent end around $A D 750$, and were buried with a variety of richly decorated weapons, tools, gaming pieces and animal bones. The rich grave goods suggest that this was a diplomatic delegation protected by a cohort of elite warriors. They were armed with swords of Scandinavian design, possibly from the Stockholm-Mälaren region, and stable isotope analysis is consistent with that being the probable homeland of the crew.

Keywords: Estonia, Pre-Viking Age, isotopic analysis, ship burial, grave goods

\section{Introduction}

Salme is a small coastal village on the island of Saaremaa in western Estonia, on the eastern side of the Baltic Sea (Figure 1). In the summer of 2008, workmen exposed extraordinary archaeological finds, including human skeletal remains, iron swords and rivets, and bone gaming pieces. The objects were dated to around $\mathrm{AD} 750$, the end of what is known in Estonia as the Pre-Viking Age, and in Sweden as the Vendel Period and the beginning of the Viking Age. None of the artefacts was of local origin, and a number of them exhibited a style associated with archaeological materials from Scandinavia, across the Baltic Sea (Konsa et al. 2009; Peets \& Maldre 2010; Peets et al. 2011, 2013). During subsequent excavations, the remains of two ships were uncovered. The ships had been dragged approximately

1 Laboratory for Archaeological Chemistry, University of Wisconsin-Madison, Madison, WI 53706, USA (Email: tdprice@wisc.edu)

2 Institute of History, Tallinn University, Rü̈̈tli 6, 10130 Tallinn, Estonia(Email: jyri.peets@ai.ee; raili.allmae@ tlu.ee; liina.maldre@ai.ee)

3 Department of Archaeology, Institute of History and Archaeology, University of Tartu, Lossi 3, 51003 Tartu, Estonia (Email: ester.oras@ut.ee) 
$100 \mathrm{~m}$ inland and partly covered with stones and soil. They were then completely buried quite quickly by marine sediments that were washed ashore by storms and perhaps carried by ice.

Here, we discuss the ship burials, the physical anthropology of the human remains, and isotopic measurements on tooth enamel from some of the burials. Our goal is to consider the place of origin of the individuals who came to Salme, met their

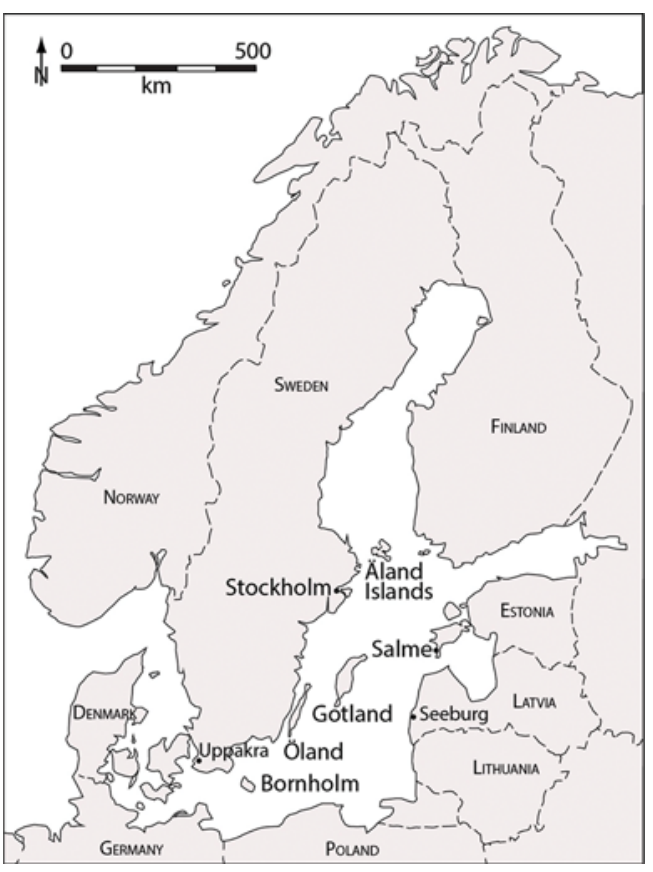

Figure 1. The Baltic Sea and some of the locations mentioned in the text. death and were buried in these two ships on the coast.

\section{The Salme ship burials}

Both ships were clinker built, with rows of iron rivets joining the overlapping horizontal planks of the hull. The Salme I ship was heavily damaged by modern construction activities. It was probably a rowing ship, approximately $11.5 \mathrm{~m}$ long, with six pairs of oars. Seven human skeletons of tall, young males were found with this ship. At least two, and perhaps all, of these individuals had been placed in a sitting position. Most of the archaeological materials were recorded outside the ship where they had been moved by the construction workers who first encountered the site. The finds included fragments of two swords, spear- and arrowheads, knives, a small, socketed axe and fragments of ornamented combs of deer antler. There were also 75 gaming pieces of whale and cattle bone, belonging to at least two separate sets, together with three dice made of antler. Animal bones (a few pig bones and lots of sheep, goat and cattle bones) at the site may have resulted from a funeral feast or been left as food for the afterlife. There were also the remains of two decapitated hawks (Konsa et al. 2009; Peets \& Maldre 2010; Allmäe et al. 2011). In Sweden, the bones of birds of prey frequently occur in wealthy burials in the sixth-tenth centuries AD. Raptor bones in graves have been found mainly in eastern Sweden, Uppland and Södermanland (Sten \& Vretemark 1988: 153; Tyrberg 2002: 228-30). The most common species is the goshawk, found in 27 of 34 graves containing raptor bones (Tyrberg 2002: 228, fig. 11).

The Salme II ship, largely preserved, was found by archaeologists in 2010, approximately 30-50m south-west of Salme I (Figure 2). The first finds included many rivets, sword fragments, two shield bosses and two human skeletons. The humerus of one of the skeletons had been chopped through in three places, and the skull of the second individual had distinct traces of axe or sword cuts. In addition, a dog skeleton was found, cut in half. 

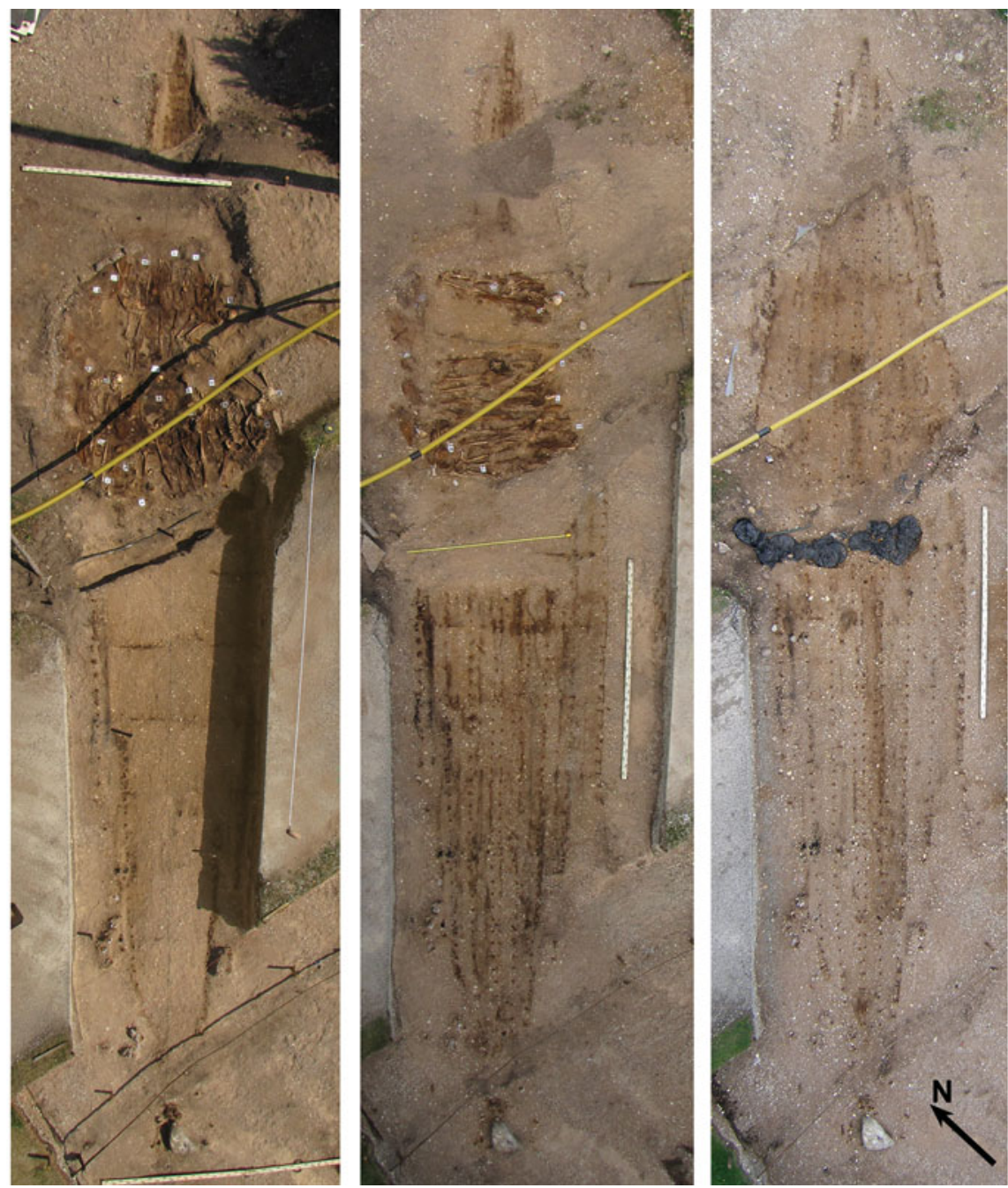

Figure 2. The Salme II ship in different stages of excavation. Left: outline of ship rivets and humus stains together with skeletons. Skeleton layers I-III are visible; middle: skeleton layer IV, located transverse to the ship; right: excavated boat contour without skeletons (photographs by Jüri Peets and Reet Maldre).

Additional excavations in 2010 and 2011 exposed the entire length of the ship, along with the skeletal remains of 34 individuals. Five or six rows of rivets used in clinker construction were preserved from the ship, which was approximately $17-17.5 \mathrm{~m}$ long and about $3 \mathrm{~m}$ wide, with a keel for sailing (Peets et al. 2013). Such a boat would have held a crew of around 30 (Henrici Chronicon Livoniae VII: 2; Tarvel 1982).

The 34 skeletons were stacked on the ship like firewood, in four layers within an area of $3 \times 4 \mathrm{~m}$. The bodies had been buried with 40 swords (both single- and double-edged types, including examples with gilded and jewelled bronze hilts), covered by large, round wooden shields with bosses of iron, and by cloth, probably from the sail. Other grave goods included 15 ornamented antler combs, broken shears, beads, pendants of bear canines, bronze and (C) Antiquity Publications Ltd, 2016 
iron plaques, and small padlocks. Gaming pieces made from whalebone and walrus ivory had been scattered among the bodies. A large number of arrowheads were found, but only a few spears and no axes. Many of the arrowheads were stuck in the wood of the ship and in the shields, and, along with the many injuries observed in the skeletal remains, document the conflict that must have resulted in the deaths of these individuals.

An important question regarding these finds concerns the origin of the individuals on the ships. The archaeological finds were non-local and pointed westwards across the Baltic to Sweden, to places such as the Mälaren region west of Stockholm, the Swedish island of Gotland, Denmark and the island of Bornholm, or south to the Swedish colony of Seeburg (also known as Grobina), near Liepaja in Courland, in present day Latvia (Nerman 1958: 198). Isotopic analysis of the Salme skeletons, looking at isotopic ratios of strontium, carbon and oxygen in dental enamel, was compared with local conditions and with data from Sweden and Denmark, and will be discussed later in this article.

\section{Anthropological analysis of the skeletal remains}

The human skeletal remains from the Salme I ship consisted largely of mixed osteological material, but the remains of seven male skeletons were recorded; the cause of their death was not obvious. The probable burial positions of the bodies were estimated from the photographs taken on site; the exact positioning of the corpses is speculative (Allmäe et al. 2011).

The positions of the human skeletons in the Salme II ship grave were recorded precisely during the excavations, using GPS equipment to facilitate 3D drawings; these demonstrate the burial arrangement and technique used in this mass grave (Figure 3). The bodies were buried in four layers, with the bottom layer perpendicular to the long axis of the ship, and the three other layers parallel to the sides of the ship (Peets et al. 2011, 2013). Edged-weapon perimortem injuries were observed on the first skeletons exposed from Salme II. The individuals had been treated with respect during burial, with dismembered body parts placed in anatomically correct positions. In total, 34 complete or partial skeletons were recorded from the grave, along with a solitary skull. Biological age and sex determinations were made according to standard criteria (WEA 1980; Buikstra \& Ubelaker 1994; White \& Folkens 2000).

For stature calculations, the maximum length of femoral bone was used; if this was absent, the humerus or tibia was used. The long bones of upper and lower extremities were measured according to Martin and Saller (1957); the right side was used if available. Stature and body weight were calculated according to formulae proposed by Ruff and colleagues (2012). The Northern European formula was used for tibia stature estimations, and the formulae of Trotter and Gleser $(1952,1958)$ were used for stature estimations (shown in brackets below). The completeness of the skeletons, any trauma, including blade wounds, and other special features were also recorded.

\section{Salme I ship grave}

From Salme I, the best-preserved skeletons in situ were SaI/1, SaI/2 and SaI/3 (Figure 4). The skeletal remains of these three men were found in the stern of the ship and were buried in rather relaxed positions (Allmäe 2011). The upper skeletons were articulated, but construction works had destroyed the lower parts of the axial skeletons. SaI/1 was lying with 

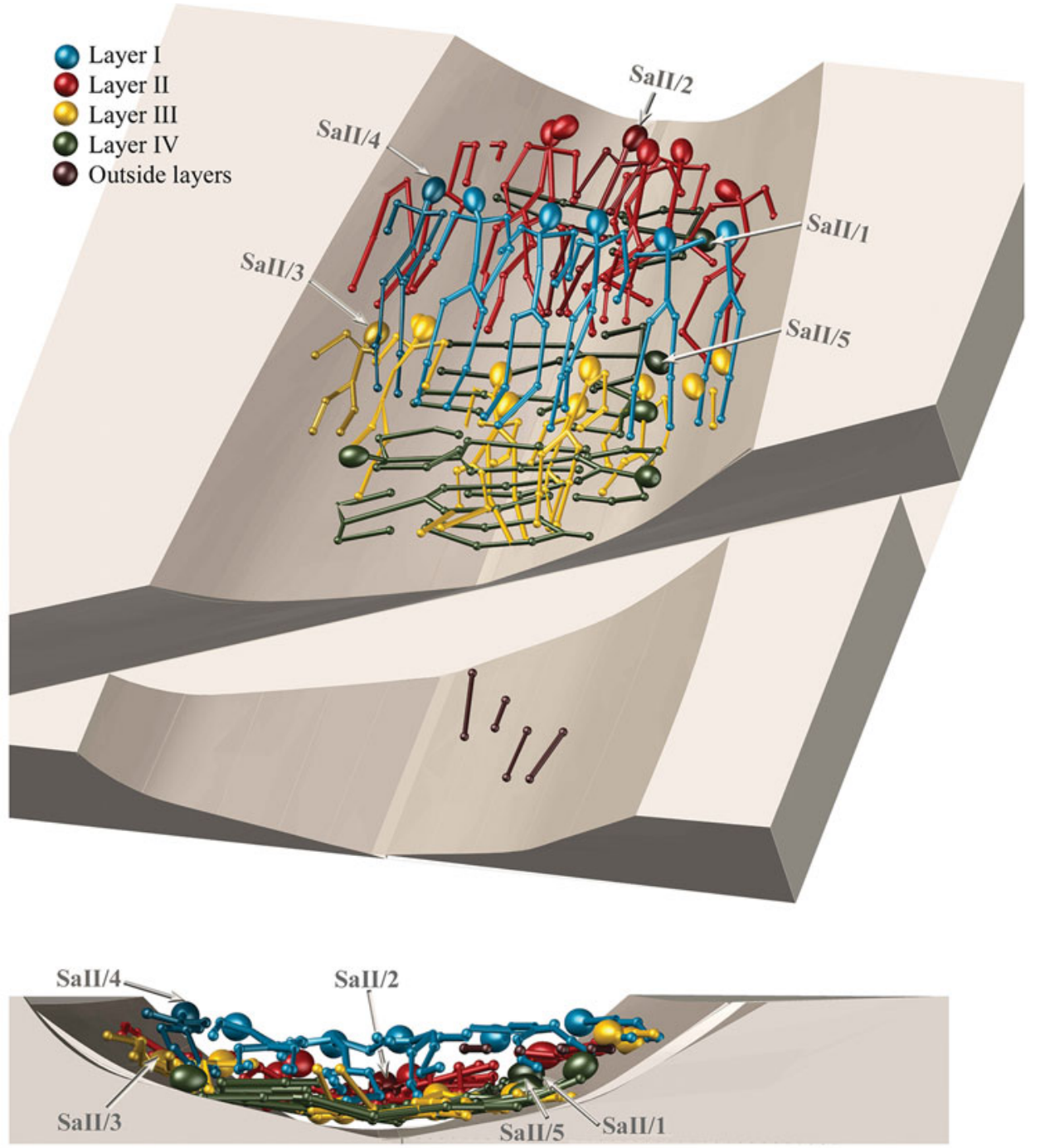

Figure 3. Schematic 3D plan of the position and distribution of burials on Salme II (drawing by Reet Maldre).

the shoulders up and the chin on the chest. This individual was a male, aged 25-35, with an estimated height of $1.812 \mathrm{~m}(1.829 \mathrm{~m})$. SaI/2 lay on his right side with his head resting on the left shoulder of SaI/1. SaI/2 was male, aged 18-25, with an approximate height of $1.747 \mathrm{~m}(1.767 \mathrm{~m})$. SaI/3 was lying prone, with his head turned to the left and his upper extremities stretched out behind him. SaI/3 was a young male, aged $25-30$, with a height of $1.793 \mathrm{~m}(1.813 \mathrm{~m})$. One premolar was collected from each individual for isotopic analysis.

\section{Salme II ship grave}

The burials in the second Salme ship were quite different, distinguished by the regular placement of the corpses in a common, extended, supine position; by the respectful attitude (C) Antiquity Publications Ltd, 2016 


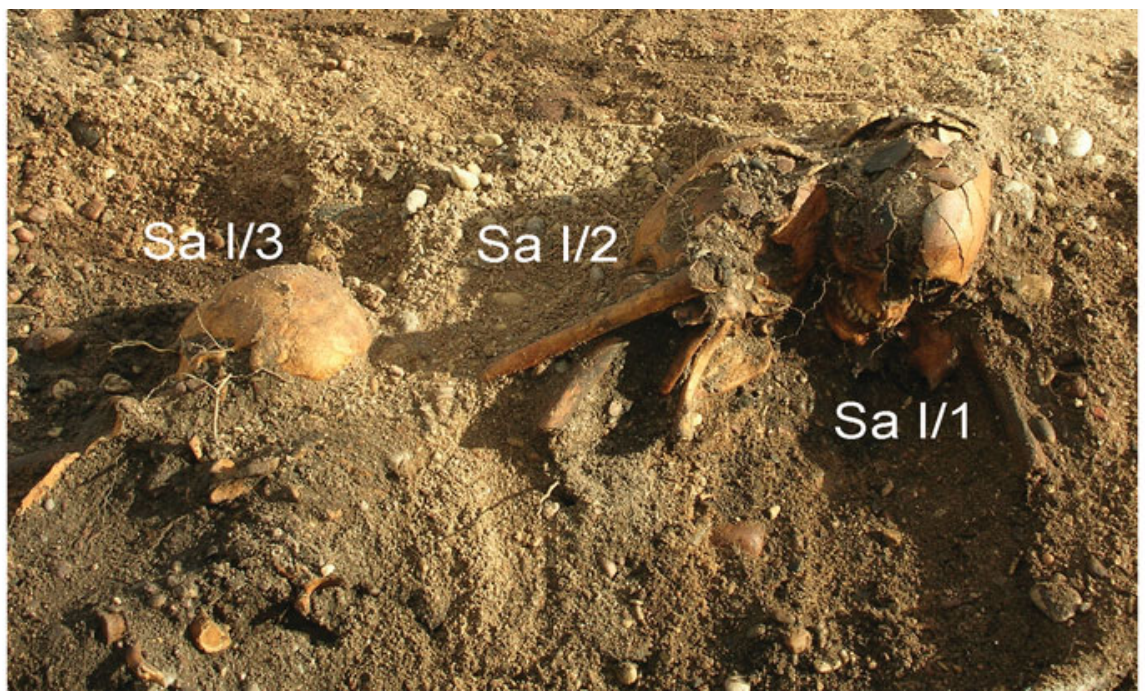

Figure 4. Upper portions of skeletons SaI/1-SaI/3, preserved in situ in the Salme I ship (photograph by Külli Rikas).

shown towards the buried individuals; and by the presence of injuries from sharp weapons. The analysis of the Salme II human remains is ongoing. To date, ten skeletons present injuries from sharp blades; six have multiple injuries and some exhibit trauma characteristic of decapitation. Investigations so far indicate an average body height of $1.743 \mathrm{~m}(1.776 \mathrm{~m})$ and body weight of $76.6 \mathrm{~kg}$.

A premolar was removed from five of the Salme II skeletons for isotopic analysis. The position of these skeletons in the mass grave is shown in Figure 3. SaII/4 is male, aged $40-60$, with an estimated height of $1.706 \mathrm{~m}(1.746 \mathrm{~m})$ and weight of $82 \mathrm{~kg}$. The remains were lying on the west side of the ship, the first in the upper burial row, in an extended supine position. The head was turned to the left, although all of the others in the upper row had their heads turned to the right. A broken sword had been placed on the right forearm, which was palm upwards. On top of this was a damaged shield boss. The skeleton exhibited several perimortem injuries: stab wounds (probably from a sword) on the posterior side of the thoracic vertebrae; five blade strokes to the right humerus, which cut through the bone in three places; and a heavy slash with a blade that caused a $100 \mathrm{~mm}$-long penetrating injury to the left side of the skull (involving both the frontal bone and the left parietal bone). Evidence of decapitation was observed on the first and second vertebrae.

Skeleton XII (SaII/2) belongs to a male, aged 25-35, height $1.691 \mathrm{~m}(1.732 \mathrm{~m})$, weight $73 \mathrm{~kg}$. Atlanto-occipital fusion was observed on the vertebra of this individual. This is one of the most common abnormalities of the upper cervical spine (Lang 1995: 54), and may cause orthopaedic problems and occasionally induce neurological effects (Skrzat et al. 2010). The skeleton exhibited blade wounds on the proximal end of the left ulna and on the medial lower edge of the femoral head. The man was buried in the second layer (Figure 3). A gaming piece with an iron tack was found near his mouth.

$\mathrm{SaII} / 3$ was the poorly preserved skeleton of a 25-35-year-old male with an estimated height of $1.704 \mathrm{~m}(1.746 \mathrm{~m})$. He was buried as the first in the second row on the west side 
of the ship. The body had been placed in an extended supine position, head turned to the left, left hand probably under the head. The right arm was stretched away from the body. A sword hilt of gilded bronze with a pommel with precious stones was found under his right upper arm, along with the head of a sacrificed dog.

SaII/5 belonged to a male, aged $25-30$. His estimated height was $1.797 \mathrm{~m}(1.822 \mathrm{~m})$ and weight $87 \mathrm{~kg}$. The man was buried in the transverse bottom layer in extended supine position, head pointed to the east and resting on the left shoulder. A full set of gaming pieces and three dice, made of whalebone and walrus ivory, were placed in his lap (probably originally in a cloth bag); a damaged sword had been placed above his left hip.

SaII/1 is a male aged $30-40$, estimated height $1.769 \mathrm{~m}(1.799 \mathrm{~m})$ and weight $79 \mathrm{~kg}$. A blade injury (probably caused by a single slashing blow) was present on the proximal end of the right ulna and distal lateral end of the left humerus. The man was buried in the transverse bottom layer, separately from the others, in the north-eastern part of the ship. He was placed in an extended supine position, with the head resting on the left shoulder. A single-edged sword had been placed between his body and left arm, parallel to the body.

In summary, the individuals buried with the two ships at Salme were young, tall males, with substantial evidence for trauma and violent death. The Salme II burials were placed carefully in the ship in laid-out positions in a stack of bodies four deep. They were buried with weapons and other grave goods. Less is known about the context of the Salme I burials due to the nature of their discovery. In addition to questions about who buried them and how they died, we would like to know where they came from.

\section{Isotopic analysis}

Light and heavy isotope ratios were measured in samples of tooth enamel taken from the three individuals from Salme I (SaI/1-SaI/3) and the five from Salme II (SaII/1-SaII/5). Premolars were chosen, as they are easier to extract and exhibit less diagnostic information than other teeth for various kinds of research. These are permanent teeth, and the enamel forms between 1.5 and 7 years of age (Woelfel \& Scheid 2002). In this study, we have measured carbonate as a component of tooth enamel using the reference standard PDB (PeeDeeBee Carbonate).

The isotopic composition of tooth enamel can provide information on diet and place of origin. Isotopic ratios of carbon, oxygen and strontium are deposited in the enamel apatite during formation and remain largely unaltered after death. In archaeology, enamel is used as a signal of place of birth. If an individual moves to a new location in a different geological context, or is buried in a new place, the enamel isotope ratio will differ from the new location, allowing the designation of that individual as non-locally born.

Light isotopes of carbon in enamel provide information on childhood diet, e.g. marine versus terrestrial resources or certain species of plants. The isotopic ratio of carbon was measured in these teeth, but the results are not discussed further. Strontium isotope analysis provides a robust means of examining past mobility. The strontium isotope ratio of ${ }^{87} \mathrm{Sr} /{ }^{86} \mathrm{Sr}$ varies among different kinds of rocks, based on their age and composition (Faure \& Mensing 2004). Strontium moves into humans from rocks and sediment through the food chain (Sillen \& Kavanagh 1982; Price 1985, 2000) and is deposited in the skeleton. Oxygen

(C) Antiquity Publications Ltd, 2016 
isotopes have been widely used as a proxy for temperature in many climate and environmental studies, and vary geographically in surface water and rainfall (Dansgaard 1964). The oxygen isotope ratio in the skeleton reflects that of body water, and ultimately of drinking water (Luz et al. 1984; Luz \& Kolodny 1985; Kohn 1996), which in turn predominantly reflects local rainfall. Major factors affecting rainfall $\delta^{18} \mathrm{O}$ values are primarily geographic: latitude, elevation, amount of precipitation and distance from the evaporation source (e.g. an ocean).

Oxygen, primarily from drinking water, is also incorporated in dental enamel-into both carbonate and phosphate ions_-during the early life of an individual, where it remains unchanged through life. Oxygen isotopes are also present in bone apatite, and are exchanged through the life of the individual by bone turnover, reflecting place of residence in later years. Thus, oxygen isotopes have the potential to be used to investigate human mobility and provenance, although there is significant variation in oxygen isotope ratios that makes their application less straightforward. Oxygen, strontium and carbon isotopes are discussed in more detail in the online supplementary material (OSM), together with procedures for sample preparation and measurement. In addition, the determination of isotopic baselines, both in principle and in practice, are described in the OSM.

\section{Estonia, Saaremaa and Salme}

Estonia sits at the edge of the Fennoscandian Shield on the north-western East European Shield (Raukas \& Teedumäe 1997). The Proterozoic igneous and metamorphic rocks of this shield form the bedrock of the country and lie at depths greater than $100 \mathrm{~m}$, increasing to the south. The sedimentary cover is composed of Cambrian, Ordovician, Silurian and Devonian materials and consists largely of limestone and sandstone. Quaternary deposits, largely of glacial origin, normally cover these sedimentary layers at depths of 5 to $>100 \mathrm{~m}$ across the rather level landscape. Alvar formations are visible in areas where the cover materials are particularly thin or absent. Although there is very little strontium isotope data from mainland Estonia, we have a few samples from the northern part of the country; values range from 0.7106-0.7159 (Oras et al. 2016). The island of Saaremaa lies on the western edge of the East European Shield. The crystalline rock basement underlying the island is composed primarily of metamorphic rocks (various forms of gneiss) in the east, while acid igneous rocks (mostly types of granite) dominate in the western part of the island (Raukas et al. 2009). The sedimentary platform on top of this basement is metres in thickness and composed entirely of Silurian carbonate rocks, primarily limestones. This limestone is exposed as alvar in areas of thin or absent surface materials.

The surface materials and topography of the island of Saaremaa are the result of the last glaciation and changes in sea level at the close of the Pleistocene. Glacial lobes moved across the island in several directions, depositing sediments from different sources, primarily to the east and west of the island. The weight of glacial ice depressed the earth's surface substantially in the Baltic, and the rise in sea level following the disappearance of this ice flooded this area during the Late Glacial. The island gradually emerged from the sea after 10000 BP, and large parts of the surface are covered with marine sediments from that period. Figure 5 provides information on the location and extent of Quaternary deposits on Saaremaa. The archaeological site at Salme lies at the head of the narrow peninsula of Sorrve Spit, a remnant 


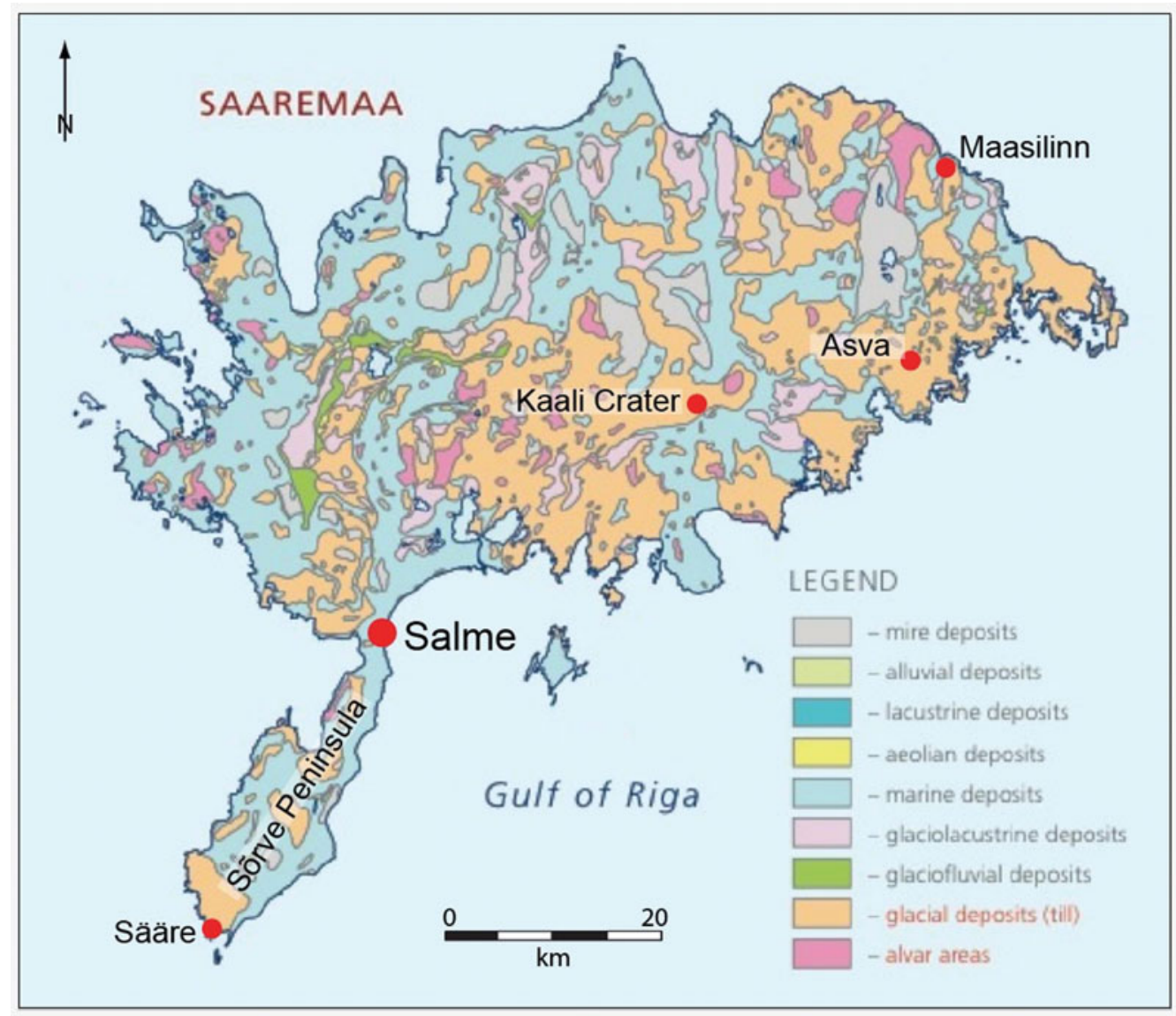

Figure 5. Quaternary deposits on the island of Saaremaa (Raukas et al. 2009), showing the location of Salme and the sites providing baseline samples from the island.

of a large esker from the late Pleistocene. The immediate area around the site is low-lying and covered with marine sediments: clays, sands and gravels.

We obtained a number of modern and archaeological faunal samples from Saaremaa to determine the local bioavailable strontium isotope ratios on the island (see Table 1). There are six samples of snail shells from four sites, and seven samples of small fauna and snails from the site of Asva, dating from the Bronze Age or Pre-Viking Age, located $44 \mathrm{~km}$ north-east of the ship burial (Figure 5). In addition, there are eight samples of human tooth enamel from Salme, discussed in the next section. The strontium isotope ratios for the snails are provided in Table 1 and Figure 6. The values show a wide range, from 0.7094 to 0.7139 . Measurement of fauna and snails from the Asva site exhibits a wide range of values with a bimodal distribution. The two snails and the rodent have ${ }^{87} \mathrm{Sr} /{ }^{86} \mathrm{Sr}$ values in line with the other snails from the island. The voles (Arvicola terrestris) have higher ratios approaching 0.720. These values, between 0.709 and 0.720 , define the maximum range for baseline values for the island.

C Antiquity Publications Ltd, 2016 
Table 1. Strontium, carbon and oxygen isotope ratios from baseline fauna and human remains from Salme and the island of Saaremaa.

\begin{tabular}{llllllll}
\hline Lab. no. & Location & \multicolumn{7}{c}{ Material } & ${ }^{87} \mathrm{Sr} /{ }^{86} \mathrm{Sr}$ & $\delta^{13} \mathrm{C}$ & $\delta^{18} \mathrm{O}$ \\
\hline Baseline fauna & Species & & Catalogue no. \\
\hline F9105 & Asva & Arvicola terrestris & enamel & AI 3658:729 & 0.7188 & -7.9 & -7.5 \\
F9106 & Asva & Arvicola terrestris & bone & AI 3799:467 (624) & 0.7189 & -11.2 & -7.8 \\
F9107 & Asva & Arvicola terrestris & enamel & AI 3799:467 (625) & 0.7199 & -9.6 & -6.8 \\
F9108 & Asva & Arvicola terrestris & bone & AI 3799:467 (491) & 0.7190 & -9.3 & -8.0 \\
F9109 & Asva & Rodentia & enamel & AI 3799:467 (492) & 0.7130 & -10.8 & -6.3 \\
F9115 & Asva & snail & shell & & 0.7097 & - & - \\
F9170 & Asva & snail & shell & & 0.7094 & - & - \\
F9113 & Maasilinn & snail & shell & & 0.7139 & - & - \\
F9114 & Kaali crater & snail & shell & & 0.7124 & - & - \\
F9116 & Sääre (Sórve) & snail & shell & & 0.7128 & - & - \\
F9171 & Sääre (Sórve) & snail & shell & & 0.7104 & - & - \\
F9118 & Kuressaare & snail & shell & & 0.7114 & - & - \\
F9172 & Kuressaare & snail & shell & & 0.7109 & - & - \\
Human & & Skeleton & & Tooth & & & \\
F9097 & Salme & SaI/1 & enamel & LRP2 & 0.7275 & -14.8 & -5.9 \\
F9098 & Salme & SaI/2 & enamel & LRP2 & 0.7299 & -15.3 & -6.2 \\
F9099 & Salme & SaI/3 & enamel & URP2 & 0.7237 & -15.3 & -5.9 \\
F9100 & Salme & SaII/1 & enamel & LRP2 & 0.7324 & -13.7 & -5.9 \\
F9101 & Salme & SaII/2 & enamel & LLP2 & 0.7282 & -14.6 & -4.6 \\
F9102 & Salme & SaII/3 & enamel & LRP2 & 0.7303 & -14.4 & -5.4 \\
F9103 & Salme & SaII/4 & enamel & LLP2 & 0.7311 & -13.6 & -5.1 \\
F9104 & Salme & SaII/5 & enamel & LRP2 & 0.7294 & -14.3 & -5.6 \\
\hline
\end{tabular}

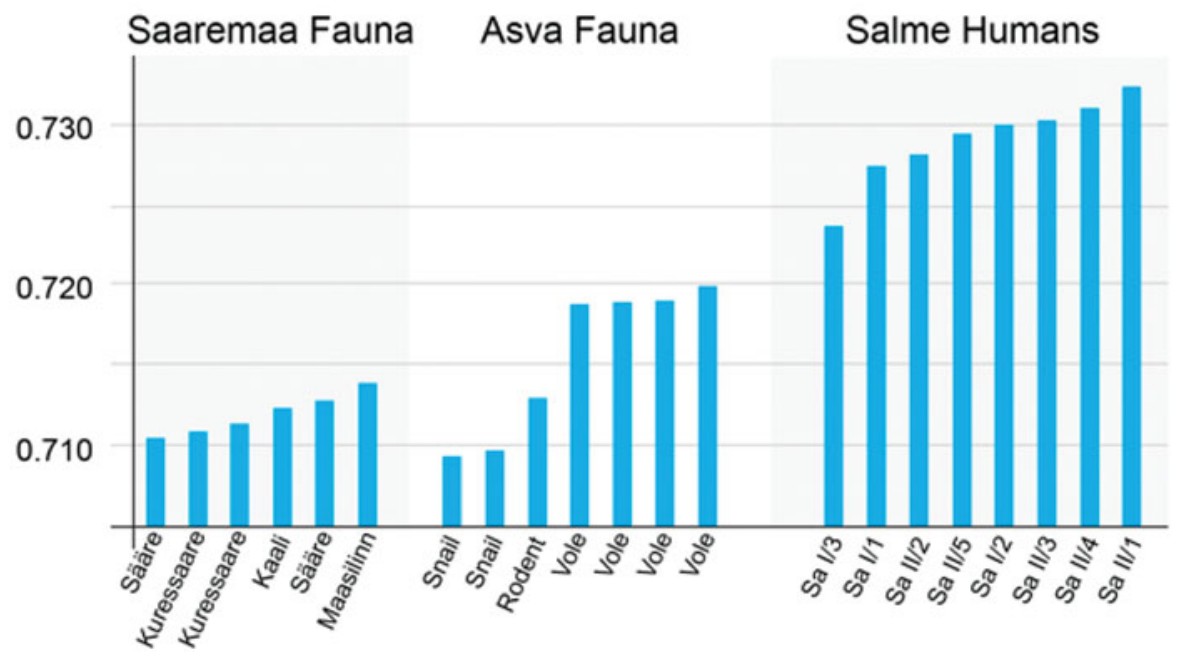

Figure 6. Faunal and human ${ }^{87} \mathrm{Sr} /{ }^{86} \mathrm{Sr}$ values from Saaremaa Island and Salme. 


\section{Isotopic analysis of the Salme human remains}

The results of the isotopic analysis of the Salme human enamel samples are provided in Table 1. The $\delta^{13} \mathrm{C}$ carbon isotope data from the enamel is a reflection of early childhood diet. It is very homogeneous in the Salme sample, and is not discussed further here. The ${ }^{87} \mathrm{Sr} /{ }^{86} \mathrm{Sr}$ for the eight Salme human samples averaged $0.7291 \pm 0.0027$ (1 SD), with a range of $0.7237-0.7324$.

The strontium isotope ratios for the Salme humans, along with faunal samples from the site and from the island of Saaremaa, are shown in Figure 6. It is very clear that the human remains from the Salme ship burials are isotopically distinct from the snails and other fauna from the larger area of the island, as well as from the baseline samples from the Asva site. This is definitive evidence that the buried individuals at Salme are not local to the island. Moreover, it is very probable that these individuals were not from the eastern Baltic region, given the geological homogeneity of this larger region, and ${ }^{87} \mathrm{Sr} /{ }^{86} \mathrm{Sr}$ values generally below 0.720 .

The oxygen isotope data are less informative. Oxygen isotope ratios in the Salme human samples averaged $-5.6 \% \pm 0.5(1 \mathrm{SD})$, ranging between $-4.6 \%$ and $-6.2 \%$. A plot of ${ }^{87} \mathrm{Sr} /{ }^{86} \mathrm{Sr}$ versus $\delta^{18} \mathrm{O}$ for the human

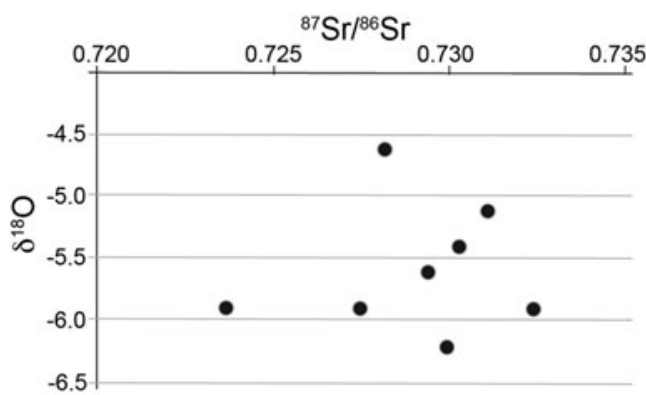
samples from Salme is shown in Figure 7. The $\delta^{18} \mathrm{O}$ values are randomly scattered, and no clear pattern can be observed. The range of $\delta^{18} \mathrm{O}$ values is not inconsistent with values from the Stockholm region in central Sweden (mean $=-6.4 \%$ ) and is slightly higher than ratios found to the south and on Gotland.

Figure 7. Scatterplot of ${ }^{87} \mathrm{Sr}{ }^{86} \mathrm{Sr}$ versus $\delta^{18} 0$ for the eight human samples from Salme.

\section{Interpretation and conclusion}

It is important to reiterate several points here. Isotopic analysis is useful for identifying non-local individuals in a burial population, but there are often a number of places with similar isotopic ratios that make the distinction of a single place of origin very difficult. In some cases, the combination of isotopic ratios (strontium, oxygen and/or lead) can help to delimit the original home of the buried individuals. Oxygen, however, is not a powerful discriminator in the Baltic region because similar values are found over a very large area. In order to constrain the possible homeland for the Salme skeletons, it is essential to combine isotopic and archaeological evidence to identify their place of origin more accurately.

The artefacts found with the burials are of particular interest. These were generally quite rich and included gaming pieces (326), swords (about 40), arrowheads (91), antler combs (15) and shield bosses (15). Certain artefact types were present in very limited quantities, including ornaments: two brooches, a handful of beads made of different materials, two bear

(C) Antiquity Publications Ltd, 2016 
canine tooth pendants, and file and shear fragments. Such limited find material, however, has a positive use. As the finds were located together and were associated with a single, short-lived event, and because they include items with considerably different dates, there is an opportunity to obtain a highly detailed chronology.

The sword hilts of gilded bronze, decorated with Scandinavian designs, and scabbard remnants with ornaments of gilded bronze or gilded bronze wire, preserved on some sword blades, provide useful information. A gilded bronze decoration on the upper edge of a scabbard from Salme (Figure 8) has an exact analogue found with the Ultuna ship burial near Uppsala, Sweden (Nerman 1958: fig. 241; Nørgård Jørgensen 1999: fig. 49: 2). A repeated, frieze-like ornamental band of gold foil and wire decorating the wooden section of another scabbard bears the same motif (Figure 9). The sword hilts of gilded bronze from the Salme ships have close parallels with the Vendel and Valsgärde ship burials near Uppsala, Sweden, and with richly furnished warrior graves in other parts of Scandinavia and Finland (Nørgård Jørgensen 1999: fig. 49: 1-3). These ornament types from inland Sweden date from the middle of the Vendel Period, i.e. AD 700-750 (Salmo 1938: pl. XLII; Kivikoski 1973: pl. 55: 507-508; Lamm \& Rundkvist 2005: 108).

The pommel of gilded bronze decorated with the image of a human-faced beast and 25 almandines (a form of garnet; Figure 10) also has close parallels, for example with the pommel

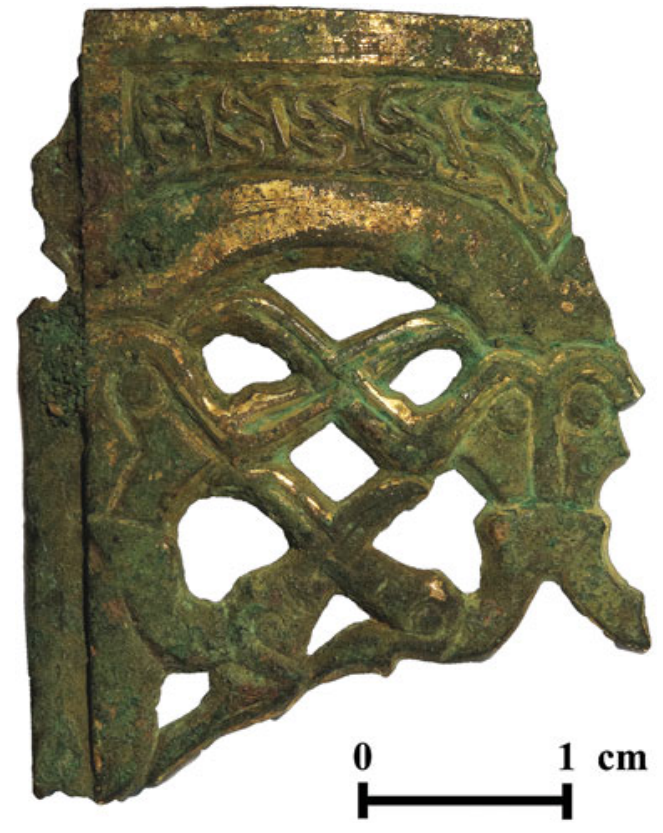

Figure 8. Fragment of the upper edge of a gilded bronze sword scabbard (photograph by Reet Maldre). depicting a beast with almandine eyes from the warrior grave with cremation burial at Ägget in the Mälaren district in Sweden, and with several burials from south-western Finland (e.g. Kivikoski 1973). The find from Ägget has been dated to the earlier phase of the Vendel Period, approximately AD 520-600 (Lamm \& Rundkvist 2005: 102-107).

During the Vendel Period, there were still relatively few large urban centres for craft production and trade in Scandinavia. Most important among them were Helgö on an island on the Mälar Lake in Uppland, and Uppåkra in south-western Sweden (Hårdh 2001). The products of jewellers at these centres were highly esteemed by local and foreign elites.

Undoubtedly, weapons decorated with precious metals, garnets and other luxury items were important gifts at negotiations of trade contracts and political alliances among aristocratic families. This practice contributed to the spread of high-status items to places quite distant from the production centres. One possible explanation for the presence of the Salme individuals in Estonia is as members of a diplomatic mission bearing gifts to promote trade and alliance. This interpretation is also supported by the fact that 
dogs and hawks had been placed with the Salme warriors as grave goods, in addition to luxury weapons and the abundant (326) gaming pieces. These items would not have been particularly suitable for a military campaign, but may be more related to the equipment of an entourage of envoys. Diplomatic deputations from that time always travelled with a well-armed cohort of elite warriors.

The luxurious sword hilts with Scandinavian decoration found at Salme II have features similar to analogous finds from rich noblemen's graves near Uppsala and other places in the Mälar region of Sweden (e.g. graves at Vendel, Valsgärde and Ultuna). The production centre at Helgö was their probable place of origin.

Several other issues are important in understanding the Salme ship burials: political relationships in Scandinavia and the Baltic, trade routes and the introduction of sailing

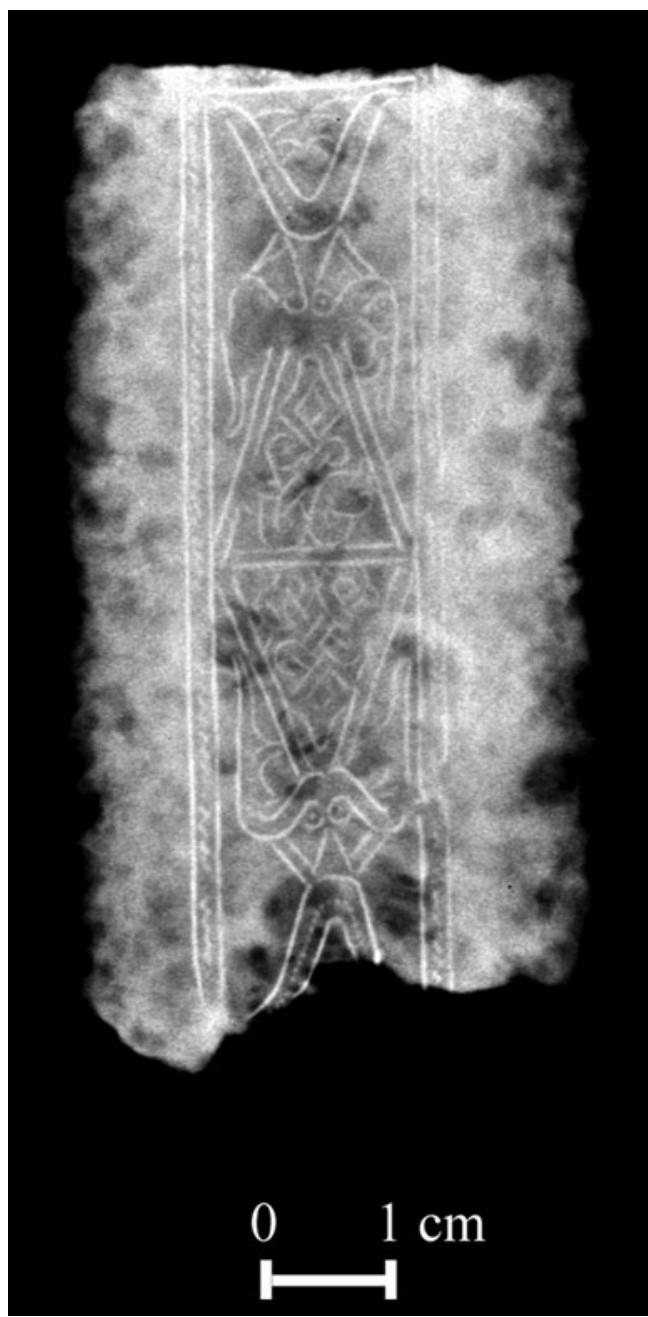

Figure 9. A frieze-like decorative band of gold foil and wire on a wooden part of a scabbard (X-ray photograph by Reet Maldre). vessels. There were two powerful groups in Sweden, known as the Svears and the Götars. The Svears lived in central Sweden, concentrated around the Uppsala area and in the Mälar region; the Götars (also known as Geats or Goths), another North Germanic tribe, lived south of the Svears, in what is now much of Götaland ('land of the Geats') in Sweden.

A central Swedish provenance for the warriors killed at Salme is supported by the location of trade routes, probably established in the Bronze Age. It is possible that there was a settlement and cemetery with a Scandinavian population on the Sorve Peninsula, which was an island separated from Saaremaa by water throughout the Middle Ages. A group of stone graves in the middle of the present Sôrve Peninsula includes two ship-like stone contours and stone cists with finds of Scandinavian design.

There were two major trade routes across the Baltic Sea. The northern route was controlled by the Svears tribal elite. The ancient seaway from Mälaren to the eastern part of the Baltic probably ran first across the archipelago of the Åland islands between Sweden and Finland, and either entered the Gulf of Finland heading east to the Great Eastern Way (Austrvegr), or south through the straits at Salme, along the island of Saaremaa to the amber-rich 

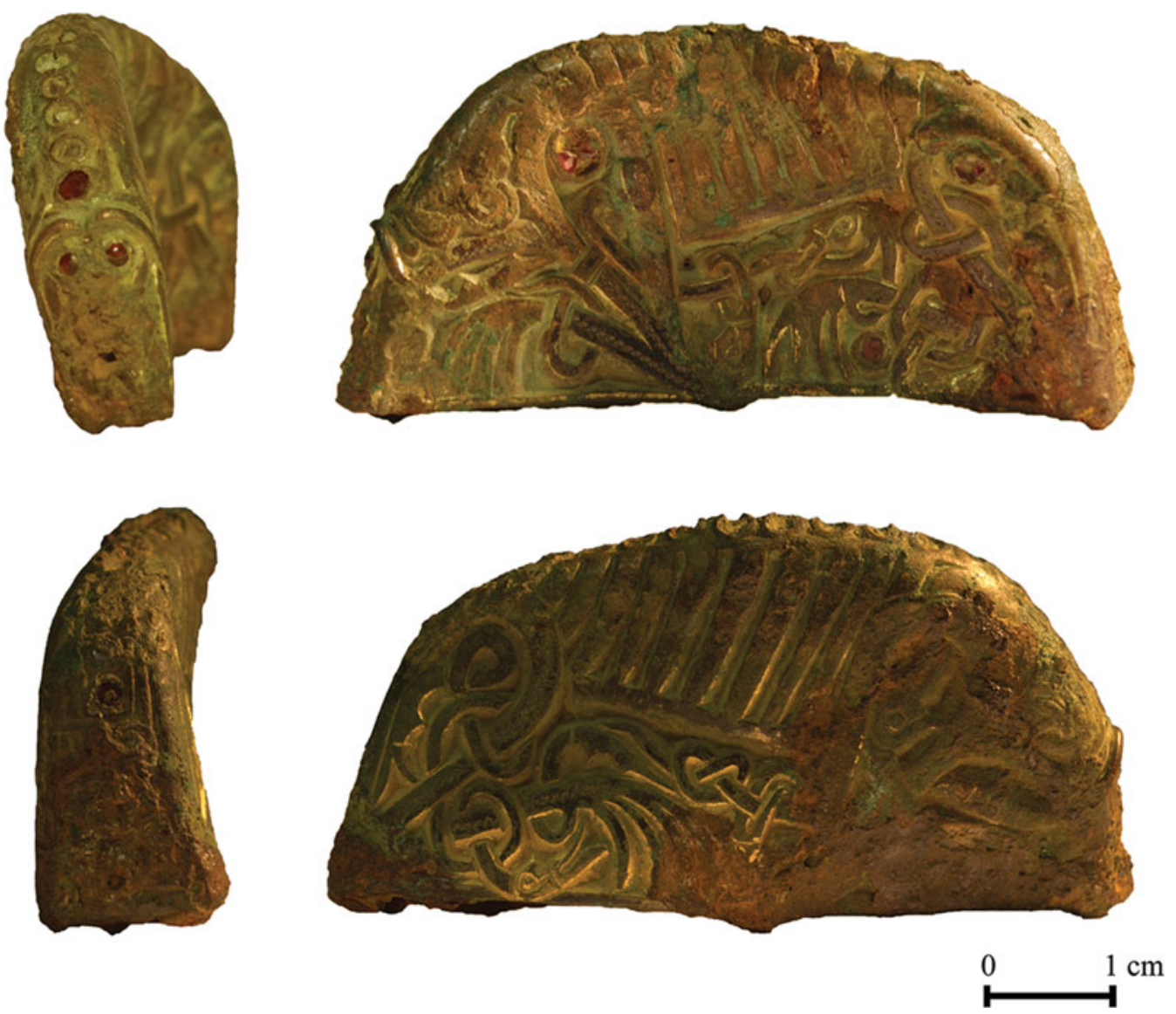

Figure 10. Four views of a sword pommel of gilded bronze, decorated with an image of a buman-faced beast and 25 almandines (photograph by Reet Maldre).

Courland region of Latvia. The Great Eastern Way was the major route from Scandinavia to Constantinople via the Gulf of Finland, the Neva River and the Dnieper River to the Black Sea, or down the Neva and Volga rivers to the Caspian Sea, and then eastwards.

The southern coast of the Baltic and the estuaries of the great rivers-the southern passage to the Great Eastern Way-were under the control of nobility from the northern part of present-day Poland, northern Germany and Denmark. There was a long-lived enmity between the courts of the Götars and the Svears over control of the Scandinavian peninsula and the Great Eastern Way, which occasionally also led to violent encounters. At times, the Norwegians also interfered in this so-called 'frozen conflict'.

The shortest route from Courland to the 'mother country' in the Mälar district ran through the Salme straits. Noblemen from Denmark and the southern coast of the Baltic, along with the Götars, wanted control of that route. It is entirely possible that the dead at Salme were the victims of an armed conflict between these foreign groups that left the Svear seafarers buried near the shoreline. Local Estonians need not have been involved in any way. 
The research reported in this study was driven by a question about the origins of the individuals buried on the two ships at Salme. The combination of isotopic and archaeological evidence clearly points to the Mälaren region in central Sweden as the most probable homeland of those men who travelled to Salme, died violently and were buried hastily in two ships in around AD 750.

\section{Supplementary material}

To view supplementary material for this article, please visit http://dx.doi.org/10.15184/aqy. 2016.106

\section{Acknowledgements}

Several individuals and institutions have contributed to the success of this project. Archaeological fieldwork on the Salme burial complex was supported by a research grant to Jüri Peets from the Estonian Ministry of Education and Science (ETF 7880), and by a target-financed research project of the Estonian Ministry of Education and Science (SF0130012s08) to Lembi Lougas. The samples for baseline values from Denmark were provided by numerous individuals named in previous publications. Collaboration with Caroline Arcini is responsible for many of the Swedish samples. Samples from Öland were collected by Helene Wilhelmsson. Ken Ritchie and Harry Robson collected the snail samples on Saaremaa; James Burton was responsible for processing the samples through the Laboratory for Archaeological Chemistry in Madison; Paul Fullagar (UNC) and David Dettman (Arizona) respectively measured the strontium and carbon/oxygen isotope ratios. Funding for the isotopic measurements was partly provided by the US National Science Foundation. The collection and analysis of baseline samples on mainland Estonia, conducted by Ester Oras, was supported by an Estonian Ministry of Education and Research institutional research grant (IUT20-7) to Valter Lang, and by the European Union, through the European Regional Development Fund (Centre of Excellence CECT).

\section{References}

ALLMÄE, R. 2011. Human bones in Salme I boat-grave, the island of Saaremaa, Estonia. Papers on Anthropology XX: 24-37.

Allmäe, R., L. Maldre \& T. TOMEK. 2011. The Salme I ship burial: an osteological view of a unique burial in Northern Europe. Interdisciplinaria Archaeologica. Natural Sciences in Archaeology 2011(2): 109-24.

BUIKSTRA, J.E. \& D. UBELAKER (ed.). 1994. Standards for data collection from human skeletal remains. Fayetteville: Arkansas Archaeological Survey.

DANSGAARD, W. 1964. Stable isotopes in precipitation. Tellus 16: 436-68. http:

//dx.doi.org/10.1111/j.2153-3490.1964.tb00181.x

FAure, G. \& T.M. MENSING. 2004. Isotopes: principles and applications. New York: Wiley.

HÅRDH, B. 2001. Unter Göttern und Königen-das religiöse und politische Zentrum Uppåkra, in B. Arrhenius (ed.) Kingdoms and regionality: transactions from the $49^{\text {th }}$ Sachsensymposium 1998 in Uppsala (Theses and Papers in Archaeology B: 6): 67-72. Stockholm: Stockholm University.

KIVIKOSKI, E. 1973. Die Eisenzeit in Finland. Bildwerk und Text. Helsinki: Neuausgabe.
KoHN, M.J. 1996. Predicting animal $\delta^{18} \mathrm{O}$ : accounting for diet and physiological adaptation. Geochimica et Cosmochimica Acta 60: 4811-29. http: //dx.doi.org/10.1016/S0016-7037(96)00240-2

Konsa, M., J. VassiljeV, R. Allmäe \& L. Maldre. 2009. Rescue excavations of a Vendel-era boat-grave in Salme, Saaremaa, in E. Oras \& E. Russow (ed.) Archaeological fieldwork in Estonia 2008: 53-64. Tallinn: Muinsuskaitseamet.

LAMM, J.P. \& M. RundKVIST. 2005. Björnen i Ägget: en vapengrav i Eds socken, Uppland och vendeltidens vapen med djurfiguriner. Fornvännen 100: 101-13.

LANG, J. 1995. Skull base and related structures: atlas of clinical anatomy. New York \& Stuttgart: Schattauer.

LuZ, B. \& Y. KOLODNY. 1985. Oxygen isotope variations in phosphate of biogenic apatites. IV: mammal teeth and bones. Earth and Planetary Science Letters 72: 29-36. http://dx.doi.org/10.1016/0012-821X(85)90047-0

LuZ, B., Y. Kolodny \& M. Horowitz. 1984. Fractionation of oxygen isotopes between mammalian bone-phosphate and environmental drinking water. Geochimica et Cosmochimica Acta 48: 1689-93.

http://dx.doi.org/10.1016/0016-7037(84)90338-7 


\section{Isotopic provenancing of the Salme ship burials in Pre-Viking Age Estonia}

Martin, R. \& K. Saller. 1957. Lehrbuch der Anthropologie, I-III. Stuttgart: Fischer.

Nerman, B. 1958. Grobin-Seeburg. Ausgrabungen und Funde (Kungl. Vitterhets Historie och Antikvites Akademien). Stockholm: Almqvist \& Wiksell.

NøRGÅRD Jørgensen, A. 1999. Waffen und Gräber. Typologische und chronologische Studien zu skandinavischen Waffengräbern 520/30 bis 900 n. Chr. Kopenhagen: Nationalmuseet.

Oras, E., V. Lang, E. RanNamäE, L. Varul, M. Konsa, J. Limbo-Simovart, G. Vedru, M. Laneman, M. Malve \& T.D. Price. 2016. Tracing prehistoric migration: isotope analysis of Bronze and Pre-Roman Iron Age coastal burials in Estonia. Estonian Journal of Archaeology 20: 3-32.

PeETs, J. \& L. MAldre. 2010. Salme paadijäänused ja luunupud, in Ü. Tamla (ed.) Ilusad asjad. Tähelepanuväärseid leide Eesti arheoloogiakogudest. 47-88. Tallinn: Ajaloo Instituut.

Peets, J., R. Allmäe \& L. MAldre. 2011. Archaeological investigations of Pre-Viking Age burial boat in Salme village at Saaremaa. Arheoloogilised välitööd Eestis. Archeological fieldwork in Estonia 2010: 29-48.

Peets, J., R. Allmäe, L. Maldre, R. SaAge, T. TomeK \& L. LÕUGAS. 2013. Research results of the Salme ship burials in 2011-2012. Arheoloogilised välitööd Eestis/Archeological fieldwork in Estonia 2012: 43-60.

PRICE, T.D. 1985. Traces of Late Archaic subsistence in the Midwestern United States. Journal of Human Evolution 14: 449-60. http: //dx.doi.org/10.1016/S0047-2484(85)80023-3

-2000 . Les isotopes du strontium dans les restes squeletiques. Étude des migrations de populations archéologiques. Les Nouvelles de l'Archeologie 80: 29-34.

Raukas, A. \& A. TeedumäE (ed.). 1997. Geology and mineral resources of Estonia. Tallinn: Estonian Academy.

Raukas, A., H. Bauert, S. Willman, E. PuUrmann \& U. RATAS. 2009. Geotourism highlights of the Saaremaa and Hiiumaa Islands. Tallinn: NGO GEOGuide Baltoscandia.
Ruff, C.B., B.M. Holt, M. Niskanen, V. SladÉK, M. Berner, E. Garofalo, H.M. Garvin, M. Hora, H. Maijanen, S. NiInimäKi, K. Salo, E. SChuplerovÁ \& D. TompKins. 2012. Stature and body mass estimation from skeletal remains in the European Holocene. American Journal of Physical Anthropology 148: 601-17. http://dx.doi.org/10.1002/ajpa.22087

Salmo, H. 1938. Die Waffen der Merowingerzeit in Finnland. Suomen Muinaismuistoyhdistyksen Aikakauskirja XLII: 127-60.

Sillen, A. \& M. KaVAnagh. 1982. Strontium and paleodietary research: a review. American Journal of Physical Anthropology 25: 67-90. http://dx.doi.org/10.1002/ajpa.1330250505

SKrZAT, J., I. MroZ, J.F. JaWOREK \& J. WALOCHA. 2010. A case of occipitalisation in human skull. Folia Morphologica 69(3): 134-37.

STEN, S. \& M. VRETEMARK. 1988. Storgravsprojektetosteologiska analyser av yngre järnålderns benrika brandgravar. Fornvännen 83: 145-56.

TARvel, E. (ed.). 1982. Henrici Chronicon Livoniae. Henriku Liivimaa Kroonika. Translated by R. Kleis. Tallinn: Eesti Raamat.

Trotter, M. \& G.C. Gleser. 1952. Estimation of stature from long bones of American whites and negroes. American Journal of Physical Anthropology 16: 463-514. http://dx.doi.org/10.1002/ajpa.1330100407

- 1958. A re-evaluation of estimation of stature based on measurements of stature taken during life and of long-bones after death. American Journal of Physical Anthropology 22: 79-123.

TyRBERG, T. 2002. The archaeological record of domesticated and tamed birds in Sweden, in Proceedings of the $4^{\text {th }}$ Meeting of the ICAZ Bird Working Group, Kraków, Poland, 11-15 September 2001 (Acta Zooloogica Cracoviensia 45 (special issue)): 215-31. Kraków: Polish Academy of Sciences.

WEA Workshop of European Anthropologists. 1980. Recommendations for age and sex diagnoses of skeletons. Journal of Human Evolution 9: 517-49.

White, T.D. \& P.A. FolKens. 2000. Human osteology. San Diego (CA): Academic.

Woelfel, J.B \& R.C. SCHEID. 2002. Dental anatomy: its relevance to dentistry. Boston (MA): Lippincott Williams \& Wilkins. 